\title{
TESTS OF RESIDUAL SHEAR TRANSFER STRENGTH OF CONCRETE EXPOSED TO FIRE
}

\author{
MUHANED A. SHALLAL ${ }^{1}$, AQIL MOUSA K. AL MUSAWI²
}

\begin{abstract}
Reinforced concrete is one of the most widely used structural components about which much scientific research has been conducted; however, some of its characteristics still require further research. The main focus of this study is the effect of direct fire on the shear transfer strength of concrete. It was investigated under several parameters including concrete strength, number of stirrup legs (the steel area across the shear plane), and fire duration. The experimental program involved the testing of two sets (groups) of specimens (12 specimens each) with different concrete strengths. Each set contained specimens of two or four stirrup legs exposed to direct fire from one side (the fire was in an open area to simulate a real-life event) for a duration of one, two, and three hours. The results of the comparison showed the importance of using high-performance concrete (instead of increasing the number of stirrup legs) to resist shear stress for the purpose of safety. A significant reduction in shear strength occurred due to the deterioration of the concrete cover after three hours of direct fire exposure.
\end{abstract}

Keywords: Fire, Shear Transfer, Compressive Strength, Reinforced Concrete, Stirrup Legs.

\footnotetext{
${ }^{1}$ Asst. Prof., PhD., Eng., Al-Qadisiyah University, Civil Engineering Department, Al-Diwania, Iraq, e-mail: mohanad.shallal@qu.edu.iq

${ }^{2}$ PhD., Eng., Al-Qadisiyah University, Roads and Transports Department, Al-Diwania, Iraq, e-mail: mohanad.shallal@qu.edu.iq
} 


\section{INTRODUCTION}

The shear transfer strength of reinforced concrete (RC) represents one of the critical zones of failure, either during increased shear stress [1], [2], [3], or under elevated temperatures [4], [5], [6], [7]. Considerable research has been published on the effect of elevated temperature on shear transfer strength, but limited information is available about the effects of direct fire exposure.The components of RC (cement paste, aggregates, and steel bars) differ in their physical properties (thermal strain), which leads to differential thermal expansion between the components corresponding to their cumulative heat values [8].

The three essential parameters that affect the shear transfer strength of concrete are: concrete resistance, steel area across the shear plane, and fire duration. High concrete strength is recommended to increase shear transfer resistance through the shear plane. This type of concrete has better interlocking and bonding between its components [3], [7], [9], causing the shear stress to be well distributed along the shear plane and therefore exhibiting a better shear transfer strength than concrete of normal strength. However, elevated temperatures cause greater expansion in concrete which is massive or has a high cement content than in concrete which is porous or has a low cement content. When the coefficients of the thermal expansion of cement paste and the aggregate differ significantly, a large change in temperature may induce a break in their interface bonding. The coefficient of thermal expansion has an important effect on the augmentation of the number of micro cracks [7], [10].

The steel area across the shear plane must be adequate enough to support the actual shear force and complemented by a factor of safety [11], but an overestimated steel area above the normal ratio will lead to minimized concrete contribution. On the contrary, the deterioration of concrete due to elevated temperatures (over $400^{\circ} \mathrm{C}$ ) will cause the stirrup to carry most of the shear stress. Therefore, it is very important to simulate the effects of fire in order to investigate residual shear strength.

The last parameter is the duration of fire contact, which represents a critical factor in the reinforced concrete structure [7], [12], [13]. Fire duration affects the thermal expansion of the concrete constituents and their conductivity due to cumulative heat storage, which increases when the duration of direct fire exposure is increased [14]. 
THE AIM OF THIS PAPER IS TO ENHANCE THE UNDERSTANDING OF THE EFFECT OF DIRECT FIRE EXPOSURE ON THE RESIDUAL SHEAR TRANSFER STRENGTH OF CONCRETE. THIS EFFECT WAS STUDIED FOR DIFFERENT CONCRETE STRENGTHS, DIFFERENT NUMBERS OF STIRRUP LEGS, AND DIFFERENT DURATIONS OF FIRE EXPOSURE.

\section{EXPERIMENTAL WORK}

The push-off test, which is one of the more practical and commonly used methods for evaluating the shear transfer strength of concrete, was used. To begin, 24 specimens $(500 \mathrm{~mm}$ in height, 300 $\mathrm{mm}$ in width, and $200 \mathrm{~mm}$ in thickness) and 24 cubic specimens $(150 \mathrm{~mm})$ of plain concrete were fabricated and divided into the following two groups of specimens according to concrete strength: Group A (1 cement: 1.5 fine aggregate: 3 coarse aggregate with a 0.48 water-cement ratio) and Group B ( 1 cement: 1 fine aggregate: 2 coarse aggregate with a 0.41 water-cement ratio). These two groups were similar in the slump test $(50 \mathrm{~mm})$ but different in concrete strength. Table 1 represents the experimental plan and specimen nominations. The first index $(0,1,2$, and 3$)$ refers to the direct fire exposure time in hours, while the second index $(0,2,4)$ refers to the number of stirrup legs across the shear plane. The shear parameter $\left(\mathrm{pf}_{\mathrm{y}}\right)$ can be calculated by:

$$
\rho f_{y}=\frac{A_{s} \times f_{y}}{b \times h}
$$

where $f_{y}=$ yield stress of steel $\left(f_{y}=543 \mathrm{MPa}\right), b=$ width of specimen $(b=200 \mathrm{~mm}), \mathrm{h}=$ height of shear plane $(\mathrm{h}=280 \mathrm{~mm})$, and $\mathrm{A}_{\mathrm{s}}=$ steel reinforcement of shear plane.

To prevent failure across the shear plane, two parts of steel reinforcement were added to each side of the specimens (see Fig. 1). The well-prepared concrete was then placed into steel molds and compacted accurately [15]. The next day, the curing process was started and continued for 21 days inside a water container. Afterwards, the specimens were removed and stored in laboratory conditions, then exposed to fire at the age of 28 days. (According to ASTM E119, the stored temperature on the inside of the specimens is less affected by direct fire in an open area than by furnace heating, due to heat dissipation.) The specimens were then cooled for one day, and afterwards the push-off test was carried out by a compressive machine. 


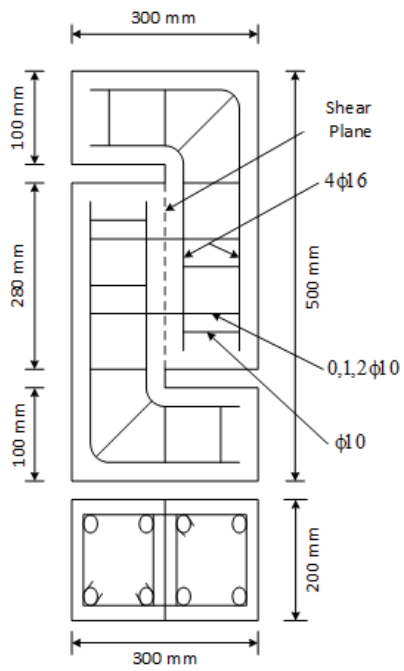

(A)

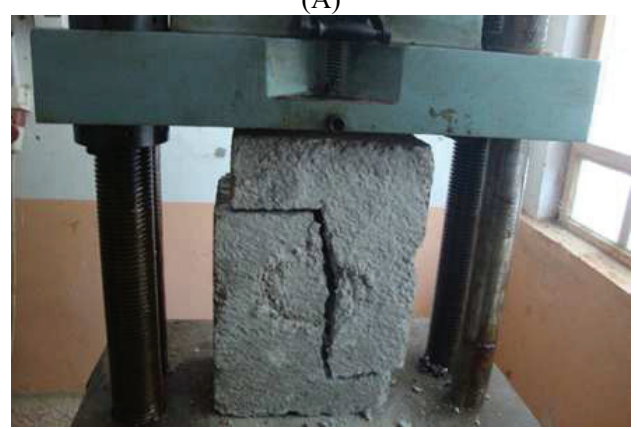

(C)

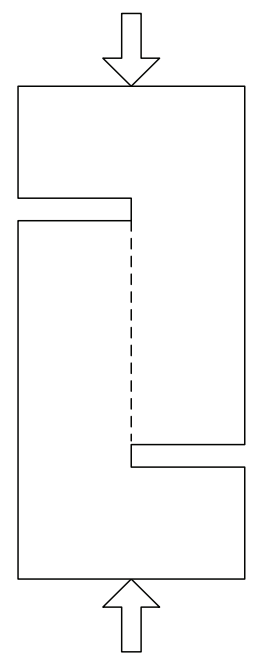

(B)

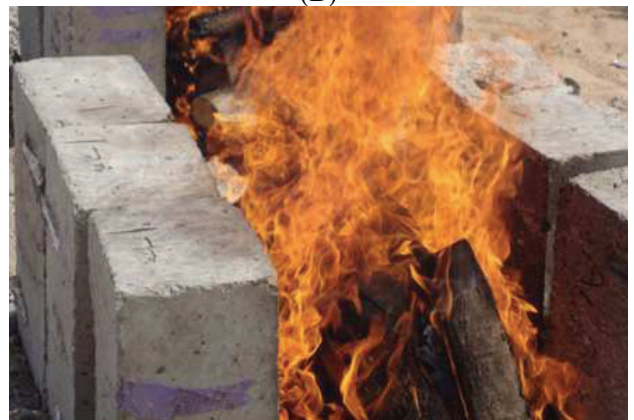

(D)

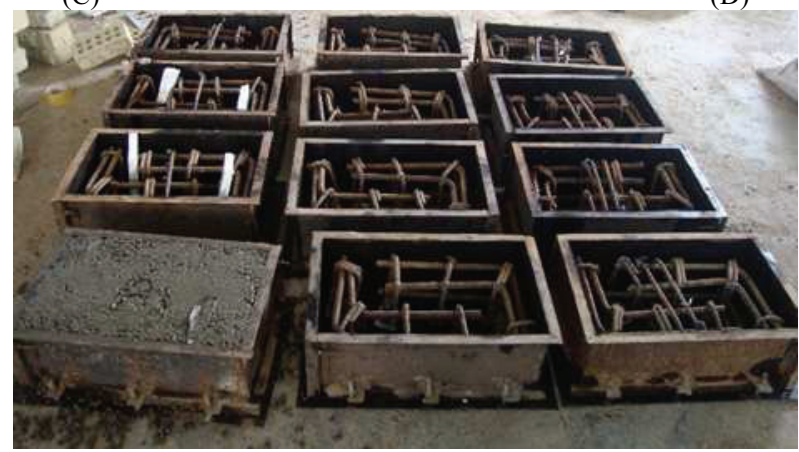

(E)

Fig. 1 (A) Dimensions and reinforcement details of push-off specimen, (B) Loading arrangement, (c) Push-off test, (D) Direct fire exposure and (E) Group of specimens. 
Table 1. Specimen name, fire duration, and shear reinforcement.

\begin{tabular}{|c|c|c|c|}
\hline Specimen No. & Fire duration $(\mathrm{hr})$ & No. of stirrup Legs & Shear Parameter \\
\hline $\mathrm{A} 0-0$ & 0 & 0 & 0 \\
\hline $\mathrm{A} 0-2$ & 0 & 2 & 1.532 \\
\hline $\mathrm{A} 0-4$ & 0 & 4 & 3.064 \\
\hline A $1-0$ & 1 & 0 & 0 \\
\hline A $1-2$ & 1 & 2 & 1.532 \\
\hline A1-4 & 1 & 4 & 3.064 \\
\hline A $2-0$ & 2 & 0 & 0 \\
\hline A2-2 & 2 & 2 & 1.532 \\
\hline A $2-4$ & 2 & 4 & 3.064 \\
\hline A3-0 & 3 & 0 & 0 \\
\hline A3-2 & 3 & 2 & 1.532 \\
\hline A3-4 & 3 & 4 & 3.064 \\
\hline B0-0 & 0 & 0 & 0 \\
\hline B0-2 & 0 & 2 & 1.532 \\
\hline B0-4 & 0 & 4 & 3.064 \\
\hline B1-0 & 1 & 0 & 0 \\
\hline B1-2 & 1 & 2 & 1.532 \\
\hline B1-4 & 1 & 4 & 3.064 \\
\hline B2-0 & 2 & 0 & 0 \\
\hline B2-2 & 2 & 2 & 1.532 \\
\hline B2-4 & 2 & 4 & 3.064 \\
\hline B3-0 & 3 & 0 & 0 \\
\hline B3-2 & 3 & 2 & 1.532 \\
\hline B3-4 & 3 & 4 & 3.064 \\
\hline
\end{tabular}

\section{RESULTS AND DISCUSSION}

Table 2 represents the results of the practical tests, showing the compressive strength of each group before and after exposure to fire. The table also shows the value of the shear transfer strength for each specimen. 
Table 2. Specimen name, fire duration, and shear transfer.

\begin{tabular}{|c|c|c|c|}
\hline Specimen No. & $\begin{array}{l}\text { Fire duration } \\
(\mathrm{hr})\end{array}$ & $\mathrm{f}_{\mathrm{cu}}(\mathrm{MPa})$ & $\begin{array}{l}\text { Shear Transfer } \\
\text { Strength (MPa) }\end{array}$ \\
\hline $\mathrm{A} 0-0$ & 0 & \multirow{3}{*}{28.01} & 4.52 \\
\hline $\mathrm{A} 0-2$ & 0 & & 7.01 \\
\hline $\mathrm{A} 0-4$ & 0 & & 8.05 \\
\hline A $1-0$ & 1 & \multirow{3}{*}{27.81} & 4.39 \\
\hline A1-2 & 1 & & 7.03 \\
\hline A1-4 & 1 & & 7.99 \\
\hline A2-0 & 2 & \multirow{3}{*}{24.86} & 3.73 \\
\hline A2-2 & 2 & & 6.43 \\
\hline A2-4 & 2 & & 7.77 \\
\hline A3-0 & 3 & \multirow{3}{*}{17.83} & 2.22 \\
\hline A3-2 & 3 & & 4.00 \\
\hline A3-4 & 3 & & 5.79 \\
\hline B0-0 & 0 & \multirow{3}{*}{44.00} & 7.15 \\
\hline B0-2 & 0 & & 9.91 \\
\hline B0-4 & 0 & & 14.73 \\
\hline B1-0 & 1 & \multirow{3}{*}{42.03} & 6.59 \\
\hline B1-2 & 1 & & 8.93 \\
\hline B1-4 & 1 & & 14.49 \\
\hline B2-0 & 2 & \multirow{3}{*}{37.62} & 5.65 \\
\hline B2-2 & 2 & & 8.46 \\
\hline B2-4 & 2 & & 14.01 \\
\hline B3-0 & 3 & \multirow{3}{*}{26.41} & 3.31 \\
\hline B3-2 & 3 & & 5.36 \\
\hline B3-4 & 3 & & 10.56 \\
\hline
\end{tabular}

\subsection{EFFECTS OF FIRE DURATION ON SHEAR TRANSFER STRENGTH OF PLAIN} CONCRETE

In plain concrete, the concrete resistance depends on its cementitious value. In fact, cement paste works as an adhesive binder between aggregate particles. An equally important factor is that shear transfer strength depends on the aggregate proportions and interlocking, especially along the shear plane. The propagation of cracks is restricted by the aggregate particles. Table 3 represents the experimental data which illustrates the effect of direct fire exposure on the compressive strength of plain concrete.

Concrete resistance decreased when fire duration increased and, not surprisingly, elevated temperatures caused more cracks due to the augmented thermal expansion of the concrete 
components. In fact, the micro-cracks passed through the cement paste and through the interfacial bond with the aggregate, and their quantity depended on cumulative heat and differential expansion. Figure 2 illustrates the typical data of the stress-strain behavior of plain concrete when exposed to various durations of direct fire. Interestingly, the percentage of strength reduction in Group B, which was higher in strength, was more significant than that of Group A, which was of normal strength. Thus, micro-cracks caused by longer fire exposure have a greater effect on high strength concrete than on normal strength concrete. On the other hand, there were no large variations in the strain values between Group B and Group A.

Table 3. Effects of fire duration on the compressive strength of two groups of plain concrete $\left(\mathrm{\rho f}_{\mathrm{y}}=0\right)$.

\begin{tabular}{|c|c|c|c|c|c|}
\hline & Fire duration (hr.) & 0 & 1 & 2 & 3 \\
\hline \multirow{2}{*}{ Group A } & $\begin{array}{c}\text { Compressive strength } \\
\text { (MPa) }\end{array}$ & 28.01 & 27.81 & 24.86 & 17.83 \\
\cline { 2 - 6 } & Reduction in strength & - & $0.7 \%$ & $11.2 \%$ & $36.6 \%$ \\
\hline \multirow{2}{*}{ Group B } & $\begin{array}{c}\text { Compressive strength } \\
\text { (MPa) }\end{array}$ & 44.00 & 42.03 & 37.62 & 26.41 \\
\cline { 2 - 6 } & Reduction in strength & - & $4.4 \%$ & $14.5 \%$ & $39.9 \%$ \\
\hline
\end{tabular}

\subsection{EFFECTS OF STIRRUP LEGS ON SHEAR TRANSFER STRENGTH}

Concrete is a brittle material with low tensile resistance. Therefore, concrete needs steel reinforcement in the tensile zone (crossing the shear plane) in order to increase its performance against shear failure [16]. The results obtained from the analysis of shear transfer strength are presented in Fig. 3. Increasing the number of stirrup legs had a significant effect of increasing the shear transfer strength, especially with high strength concrete (Group B). This result was expected due to steel contribution. The high concrete strength group (Group B) exhibited better performance than the normal strength one (Group A). Possible explanations for this behavior might be the high bonding strength between the concrete and the steel bars [17], as well as the steel reinforcement restricting the micro-cracks and their propagation along the shear plane. 


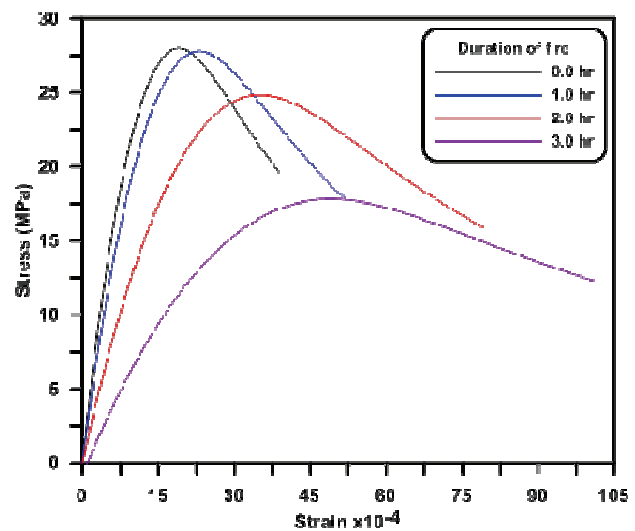

(A)

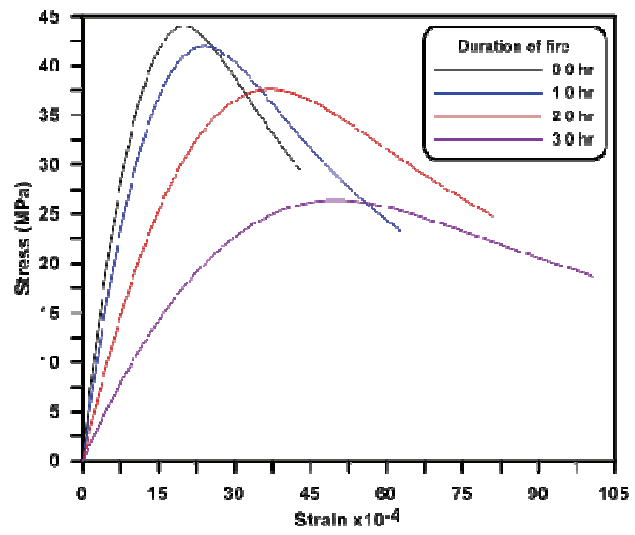

(B)

Fig. 2. Stress-strain relationship (A) Group A and (B) Group B.

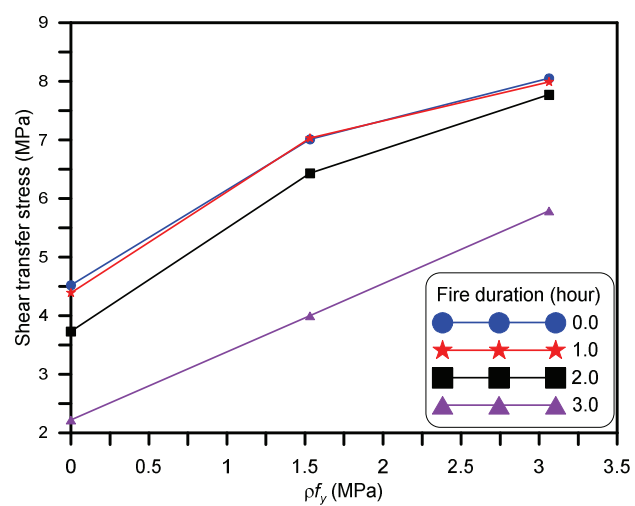

(A)

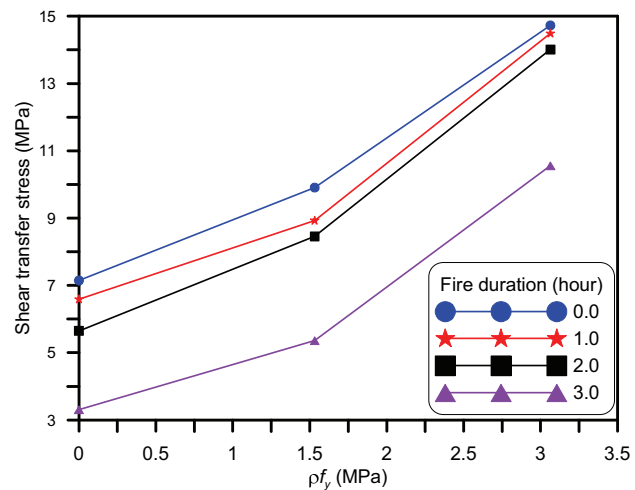

(B)

Fig. 3. Effects of different shear reinforcements on shear transfer strength (a) Group A and (b) Group B.

\subsection{EFFECTS OF FIRE DURATION ON SHEAR TRANSFER STRENGTH OF REINFORCED CONCRETE}

Cumulative temperature can cause strain concentrations at the aggregate-paste interface. Therefore, when fire exposure time is increased, concrete strength will gradually decrease due to micro-crack propagation and/or generation [18]. As shown in Fig. 4, experimental results show a drop in strength for both Group A and Group B. 
A slight decrease in shear transfer strength occurred during the first two hours of direct fire exposure, and then a dramatic drop in strength occurred after the first two hours. In addition to the effects of the micro-cracks, another possible explanation for this drop in strength could be the spall of the concrete cover (reduction in shear plane area). The steel reinforcement was exposed to direct fire as well (Fig. 5).

As expected, the burned reinforced concrete specimens showed more residual shear transfer strength than the plain concrete specimens due to steel participation, which occurred across the shear plane (Fig. 6).

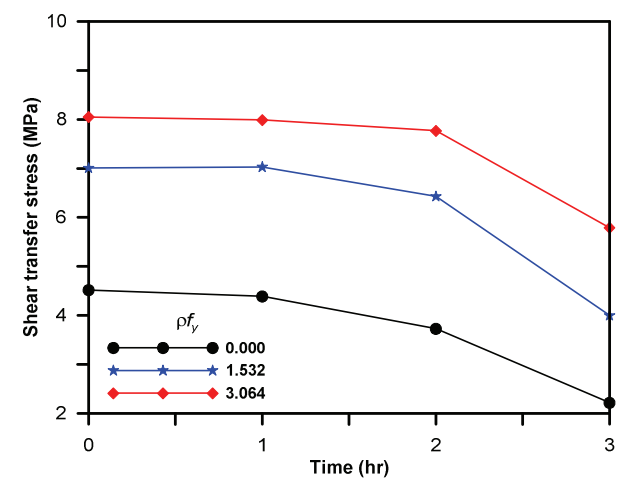

(A)

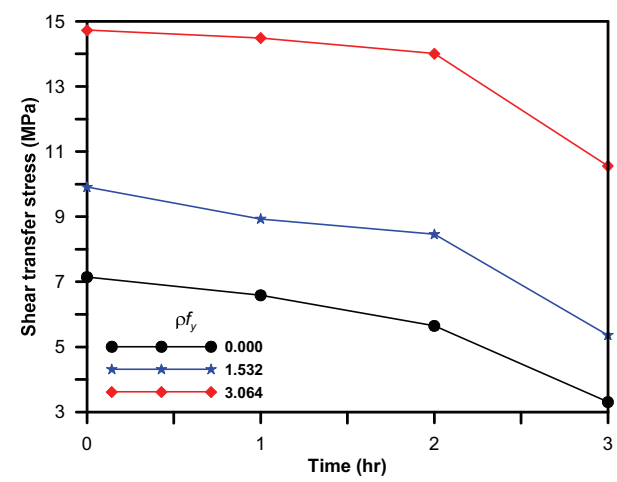

(B)

Fig. 4. Effects of fire duration on shear transfer strength for different shear reinforcements (A) Group A and (B) Group B.

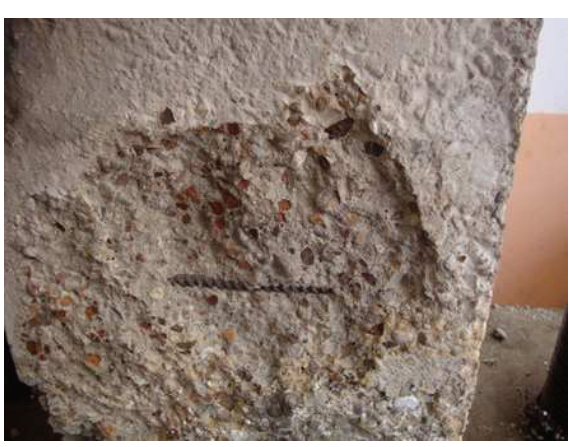

(A)

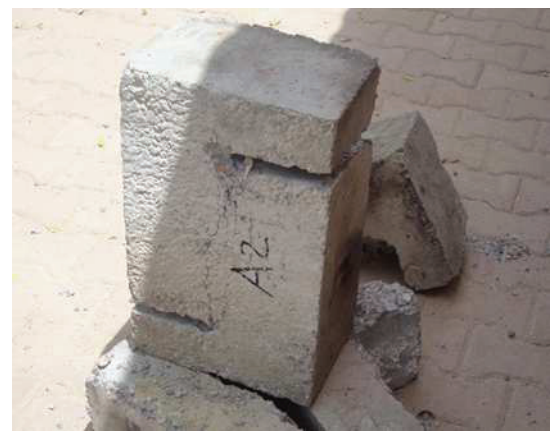

(B)

Fig. 5. Effects of direct fire (A) after three hours. (B) Second surface which was not exposed to fire. 


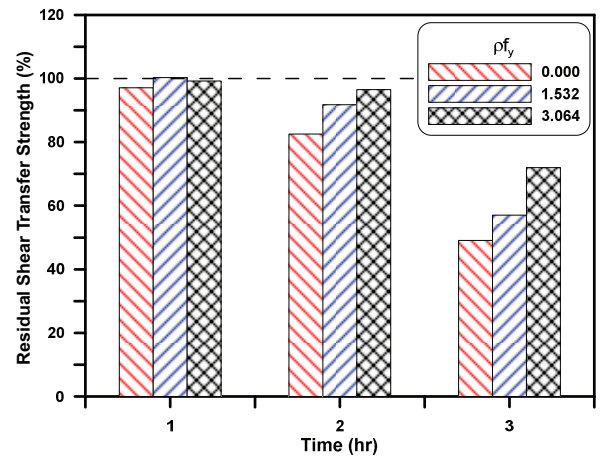

(A)

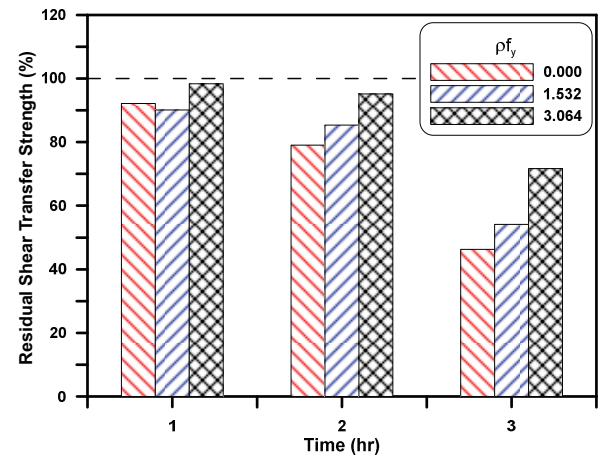

(B)

Fig. 6. Residual shear transfer strength versus fire exposure time for different shear reinforcements (A) Group A and (B) Group B.

One unanticipated finding was that during the first hour the residual shear transfer strength of Group A either stayed at the same level or underwent some modifications for the reinforced specimens. One hour of direct fire exposure in an open area did not have a significant effect on concrete strength (due to heat dissipation). On the other hand, when concrete is exposed to a low temperature, concrete resistance might increase due to the elimination of the moisture effect.

Finally, it was interesting to collect all of the abovementioned results and visualize them in a single diagram (Fig. 7) which illustrates the effects of concrete strength and steel reinforcement on shear transfer strength.

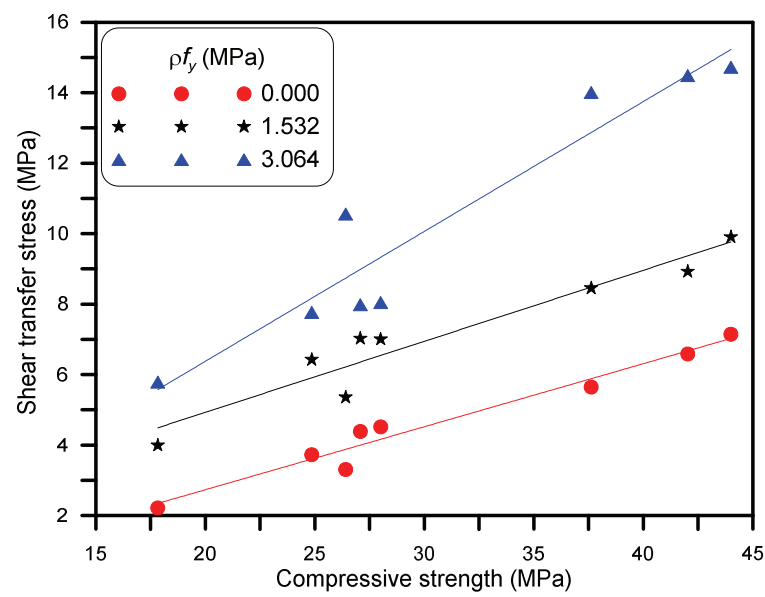

Fig. 7. Effects of concrete strength and shear reinforcement on shear transfer strength. 


\section{CONCLUSION}

This study confirms the importance of using high performance concrete (rather than increasing the number of stirrup legs) for resisting shear stress. The residual shear transfer strength of high performance concrete (Group B) was better than that of normal concrete (Group A) when other conditions were fixed (number of stirrup legs and fire duration). From an engineering standpoint, increasing steel reinforcement will pose a greater danger of causing sudden failure when the steel bars reach a yielding point due to elevated temperatures. After three hours of direct fire exposure Group A, which had a residual strength of $28 \mathrm{MPa}$, lost about $50 \%, 42 \%$, and $28 \%$ of its shear transfer strength resistance for the specimens of plain concrete with two stirrup legs and four stirrup legs, respectively. The concrete with a compressive strength of $44 \mathrm{MPa}$ (Group B) lost about 53\%, $45 \%$, and $39 \%$ of its shear transfer resistance for the specimens of plain concrete with two stirrup legs and four stirrup legs, respectively. Hence, fire exposure time had a greater effect on Group B than on Group A. There are still many unanswered questions about the thermal properties of concrete, most of which depend on mixture aggregate components (physical properties and mix proportions). 


\section{REFERENCES}

1. Xuehui A.N, Maekawa K., Okamura H., "Numerical simulation of size effect in shear strength of RC beams", Doboku Gakkai Ronbunshu, 1997 (564): 297-316, 1997.

2. Zhao P., Kang S., Yang B., "Shear Strength of Engineered Cementitious Composites under Push-Off Loads", Procedia Engineering, 210: 53-60, 2017.

3. Hsu T. T. C, Mau S. T., Chen B., "Theory on shear transfer strength of reinforced concrete", Structural Journal, 84: 149-160, 1987.

4. Xiao J., Li Z., Li J., "Shear transfer across a crack in high-strength concrete after elevated temperatures", Construction and Building Materials, 71: 472-483, 2014.

5. Quintiere J. G., "Fundamentals of fire phenomena". Chichester. John Wiley, 2006.

6. Khoury G. A., "Effect of fire on concrete and concrete structures", Progress in Structural Engineering and Materials, 2: 429-447, 2000.

7. Arioz O., "Effects of elevated temperatures on properties of concrete", Fire safety journal, 42: 516-522, 2007.

8. Ramachandran V. S., Paroli R. M., Beaudoin J. J., "Handbook of thermal analysis of construction materials". William Andrew, 2002.

9. Naus Dan J., "The Effect of Elevated Temperature on Concrete Materials and Structures-a Literature Review", Oak Ridge National Laboratory, ORNL, 2006.

10. Rahal K. N., Khaleefi A. L., Al-Sanee A., "An experimental investigation of shear-transfer strength of normal and high strength self coMpacting concrete", Engineering Structures, 109: 16-25, 2016.

11. Park R., Paulay T., "Reinforced concrete structures". John Wiley \& Sons, 1975.

12. Lim L., Buchanan A., Moss P., Franssen J., "Numerical modelling of two-way reinforced concrete slabs in fire", Engineering structures, 26: 1081-1091, 2004.

13. Xavier, Hélder Francisco, "Analysis of reinforced concrete frames exposed to fire: based on advanced calculation methods", Master Thesis, Faculty of Engineering, University of Porto, Portugal, 2009.

14. Guo Z. Shi X., "Experiment and calculation of reinforced concrete at elevated temperatures" . Waltham, USA: Elsevier Inc, 2011.

15. ACI Committee 318: Building Code Requirements for Structural Concrete (ACI 318-14) and Commentary, Farmington Hills, 2014.

16. Mattock A. H. Hawkins N. M., "Shear transfer in reinforced concrete-recent research", Journal precast / prestressed concrete institute. 17: 55-75, 1972.

17. Kahan, L. F. Mitchell A. D., "Shear friction tests with high-strength concrete", Structural Journal, 99: 98-103, 2002 .

18. Al-Owaisy S. R., "Effect of High Temperatures on Shear Transfer Strength of concrete", Engineering and Development, 11: 92-103, 2007. 


\section{LIST OF FIGURES AND TABLES:}

Fig. 1. (A) Dimensions and reinforcement details of push-off specimen, (B) Loading arrangement, (c) Pushoff test, (D) Direct fire exposure and (E) Group of specimens.

Rys. 1 (A) Wymiary i szczegóły zbrojenia próbki odpychającej, (B) Rozkład obciążeń, (C) Badanie odpychania, (D) Bezpośrednie poddawanie działaniu ognia i (E) Grupa próbek.

Fig. 2. Stress-strain relationship (A) Group A and (B) Group B.

Rys. 2. Związek naprężeń i odkształceń (A) grupa A i (B) grupa B.

Fig. 3. Effects of different shear reinforcements on shear transfer strength (a) Group A and (b) Group B.

Rys. 3. Wpływ różnych zbrojeń ścinanych na siłę wytrzymałości na ścinanie (a) Grupa A i (b) Grupa B.

Fig. 4. Effects of fire duration on shear transfer strength for different shear reinforcements (A) Group A and (B) Group B.

Rys. 4. Wpływ czasu trwania pożaru na siłę wytrzymałości na ścinanie dla różnych zbrojeń ścinanych (A) Grupa A i (B) Grupa B.

Fig. 5. Effects of direct fire (A) after three hours. (B) Second surface which was not exposed to fire. Rys. 5. Wpływ bezpośredniego ognia (A) po trzech godzinach. (B) Druga powierzchnia, która jest poddawania działaniu ognia.

Fig. 6. Residual shear transfer strength versus fire exposure time for different shear reinforcements (A) Group A and (B) Group B.

Rys. 6. Resztkowa siła wytrzymałości na ścinanie w stosunku do czasu poddawania działaniu ognia dla różnych zbrojeń ścinanych (A) Grupa A i (B) Grupa B.

Fig. 7. Effects of concrete strength and shear reinforcement on shear transfer strength.

Rys. 7. Wpływ wytrzymałości betonu i zbrojenia ścinanego na siłę wytrzymałości na ścinanie.Tab. 1.

Specimen name, fire duration, and shear reinforcement.

Tab. 1. Specimen name, fire duration and shear reinforcement.

Tab. 1. Nazwa próbki, czas trwania pożaru i zbrojenie ścinane.

Tab. 2. Specimen name, fire duration, and shear transfer.

Tab. 2. Nazwa próbki, czas trwania pożaru i przenoszenie ścinania.

Tab. 3. Effects of fire duration on the compressive strength of two groups of plain concrete $\left(\rho f_{y}=0\right)$.

Tab. 3. Wpływ czasu trwania pożaru na wytrzymałość na ściskanie dwóch grup zwykłego betonu ( $\rho \mathrm{f}_{\mathrm{y}}=0$ ). 